\title{
Plant extracts in agriculture and their applications in the treatment of seeds
}

\author{
Ricardo da Silva Carvalho ${ }^{1^{*} \text { (D) }}$ Mariana Altenhofen da Silva ${ }^{1}$ (iD \\ Maria Teresa Mendes Ribeiro Borges ${ }^{1}$ (D) Victor Augusto Forti ${ }^{1}$ (D)
}

${ }^{1}$ Departamento de Tecnologia Agroindustrial e Socioeconomia Rural, Universidade Federal de São Carlos (UFSCar), Campus de Ciências Agrárias, 136004-900, Araras, SP, Brasil. E-mail: richadcarvalho1@gmail.com. "Corresponding author.

ABSTRACT: The harmful effects caused by the use of toxic substances in agriculture have led to the development of alternative solutions, and researchers have focused on understanding the effectiveness and potential of plant extracts in agriculture. The aim of this systematic review was to understand the situation of research and scientific dissemination, as well as how current science has approached the use of plant extracts in agriculture, especially in seed applications. There is potential on the use of plant extracts in agriculture, demonstrated by a high number of publications over the last ten years, especially in the years 2018, 2019 and 2020, and Brazil stands out as the main country on this research area. Control of phytopathogenic microorganisms, insect control, biostimulant effect, resistance induction and herbicide effect have been the main themes explored for use in agriculture. The direct application of plant extracts is centered on plants and seeds, being this latter mainly focused on the control of phytopathogenic organisms and biostimulating effect.

Key words: biostimulant effects, insect control, phytopathogenic organisms, seed health.

Extratos vegetais na agricultura e suas aplicações no tratamento de sementes

RESUMO: Em resposta aos efeitos nocivos da utilização de substâncias toxicas na agricultura, a ciência tem avançado no desenvolvimento de soluções alternativas, visando compreender a eficácia e o potencial de extratos vegetais na agricultura. Objetivou-se com esta revisão sistematizada compreender a situação da pesquisa e divulgação cientifica, bem como a maneira que a ciência atual tem abordado o uso de extratos vegetais na agricultura, especialmente na aplicação em sementes. $O$ uso de extratos vegetais na agricultura tem potencial demonstrado pelo elevado número de publicações nos últimos dez anos, com destaque para os anos de 2018, 2019 e 2020, sendo o Brasil o país de maior produção de trabalhos voltados à essa área de estudo. Os temas controle de microrganismos fitopatogênicos, controle de insetos, efeito bioestimulante, indução de resistência e efeito herbicida tem sido os principais temas explorados para uso na agricultura. A aplicação de extratos vegetais é centrada principalmente em organismos fitopatogênicos associados a plantas e sementes, sendo que, para a aplicação em sementes, o foco está no controle de organismos fitopatogênicos e efeito de promoção de crescimento.

Palavras-chave: controle de insetos, promoção de crescimento, organismos fitopatogênicos, sanidade de sementes.

\section{INTRODUCTION}

The process of agriculture expansion and the greater demand for food in recent years led to the rise in the use of synthetic products that are toxic for the management of production fields, which has been triggering a set of problems to the environment, farmers and consumers (SCHÜTTE et al., 2017).

Given the need for the application of ecological strategies in agriculture, there is an increasing interest in research in different areas, which aim to explore the potentialities of the plant extracts in agriculture (ARSHAD et al., 2019; ALMOHMADI; AL-ANI, 2019). The plant extracts acts as inducers of resistance in plants (COSTA et al., 2019), as biostimulants (COZZOLINO et al., 2020), have herbicide effect (ZAKA et al., 2019; FINDURA et al., 2020), nematicides (MÜLLER et al., 2016; COLTRO-RONCATO et al., 2016) and insecticides effects (PAVELA et al., 2018); and especially, fungicide effect for the control of phytopathogenic organisms (MEENA et al., 2020; NCISE et al., 2020).

There are innumerable potentialities for plant extracts in agriculture. The application in seed treatment has been explored as an alternative (KARABÜYÜK\& AYSAN, 2019) for diverse purposes, especially in the control of phytopathogenic organisms linked to seeds. (MANGWENDE et al., 
2019; CHANDEL \& KUMAR, 2017). Other purposes are biostimulant effect on germination and initial seedling establishment (RAFI et al., 2015), inducers of resistance in seedlings after emergence (ALSAHLI et al., 2018) and bioherbicides effect when related to the establishment of spontaneous plants (FINDURA et al., 2020; KAAB et al., 2020).

In agriculture, the seed has an important role, since it corresponds to the beginning of the stage of formation of an agricultural production field, and its quality can be affected by the presence of phytopathogenic organisms and pests (MAXIMIANO et al., 2018; PARIKH et al., 2018) which can damage the seeds during storage (WORDELL FILHO et al., 2016). Therefore, searching for a more sustainable agriculture, plant extracts have also been tested as an important tool for seed treatment (KAMRAN et al., 2013; CHANDEL \& KUMAR, 2017; OJO et al., 2020).

Despite the intensification in the number of studies that aim to understand the efficacy and potential of plant extracts, this information is still very specific to the biological systems analyzed, without encompassing the production systems and all potentialities of application, generating gaps that need to be better understood. For this, in addition to the application of plant extracts, it becomes necessary to understand how and where the research in this field has been performed and disseminated, generating useful information for planning, executing and publishing future research directed to the use of plant extracts in agriculture, focusing on the application in seeds.

Given the above, the aim of this research was to understand, by a systematic review, the situation of research and scientific dissemination, as well as how current Science has been approaching the topic of the use of plant extracts in agriculture, especially the application in seeds.

\section{Development}

For the accomplishment and constitution of the scope of this systematic review, articles indexed in the database Web of Science were selected, since it is the main worldwide database for the indexing of articles linked to journals with high international visibility.

For a better definition of the terms for the search, previous searches were performed using different strategies based on boolean operators, using basic search, with a time frame from 2010 to August 2020. After the analysis of this search and evaluating the articles aligned with the topic of the review, the following set of key terms was defined: "plant" extract" and agriculture; "plant" extract" "and "seed" treatment"; "plant" extract" and "alternative control"; "plant" extract"" and "seed germination" and "plant" extract", and seed fungi. The inclusion criterion was defined as only those studies applied and directly related to the use of plant extracts in agriculture and; therefore, articles of review, and of the fields of zootechnics, medicine, fishing engineering, veterinary and researches that were not related to the subject in question were not selected.

Therefore, 283 articles were selected, which were dealing with and making reference to the subject of study of this review. They were once more evaluated, excluding 82 duplicated, totalizing 201 studies in the final scope of the systematic review that were identified in relation to the year of publication, associated journal and countries in which the research was developed.

Subsequently, the guiding criteria and topics for data analysis were defined, namely: $1^{\text {st }}$ Use in agriculture: (A) Insects: control of insect pests/ effect on the biology of insects/insect repellency; (B) Phytopathogenic organisms: control of diseases/effect on the biology of fungi/bacteria/nematodes (in vitro/ in vivo/both); (C) Herbicide effect: allelopathic effect/ control of plants; (D) Resistance induction: resistance to insects/pathogens/abiotic factors; (E) Biostimulant effect: growth promotion effect/production; (F) Others; $2^{\text {nd }}$ Application: (A) Plant (in vitro/in vivo/both); (B) Postharvest (in vitro/in vivo/both); (C) Seeds (in vitro/in vivo/both) and (D) Others. $3^{\text {rd }}$ Use intended for application in seeds: (A) Phytopathogenic organisms; (B) Pests; (C) Resistance; (D) Biostimulant and (E) Others.

The quali-quantitative analysis of the selected articles was performed using the bibliometric indicators, with the discrimination of the following items: title, year of publication, journal, country of research, topic in agriculture, application, and application in seeds. The data were subjected to analysis in Rstudio version 2020, and graphs and word clouds were created.

Regarding the year of publication, the highest frequency was verified in 2019 , followed by 2018. A great number of publications was observed until August 2020, with the prediction that, until the end of the year, they would outnumber those of 2019. On the other hand, between years 2010 and 2017, a stability was observed in relation to the number of articles published on this topic (Figure 1).

In recent years, one of the main demands of the population and a challenge faced by the agricultural sector is the need for safer and more sustainable approaches regarding the management of agricultural production systems in view of the harmful effects generated by the high toxicity and low biodegradability of diverse synthetic agrochemicals used (BOITEUX et al., 2019). An increase in the visibility of researches using plant extracts in agriculture is then perceived, 


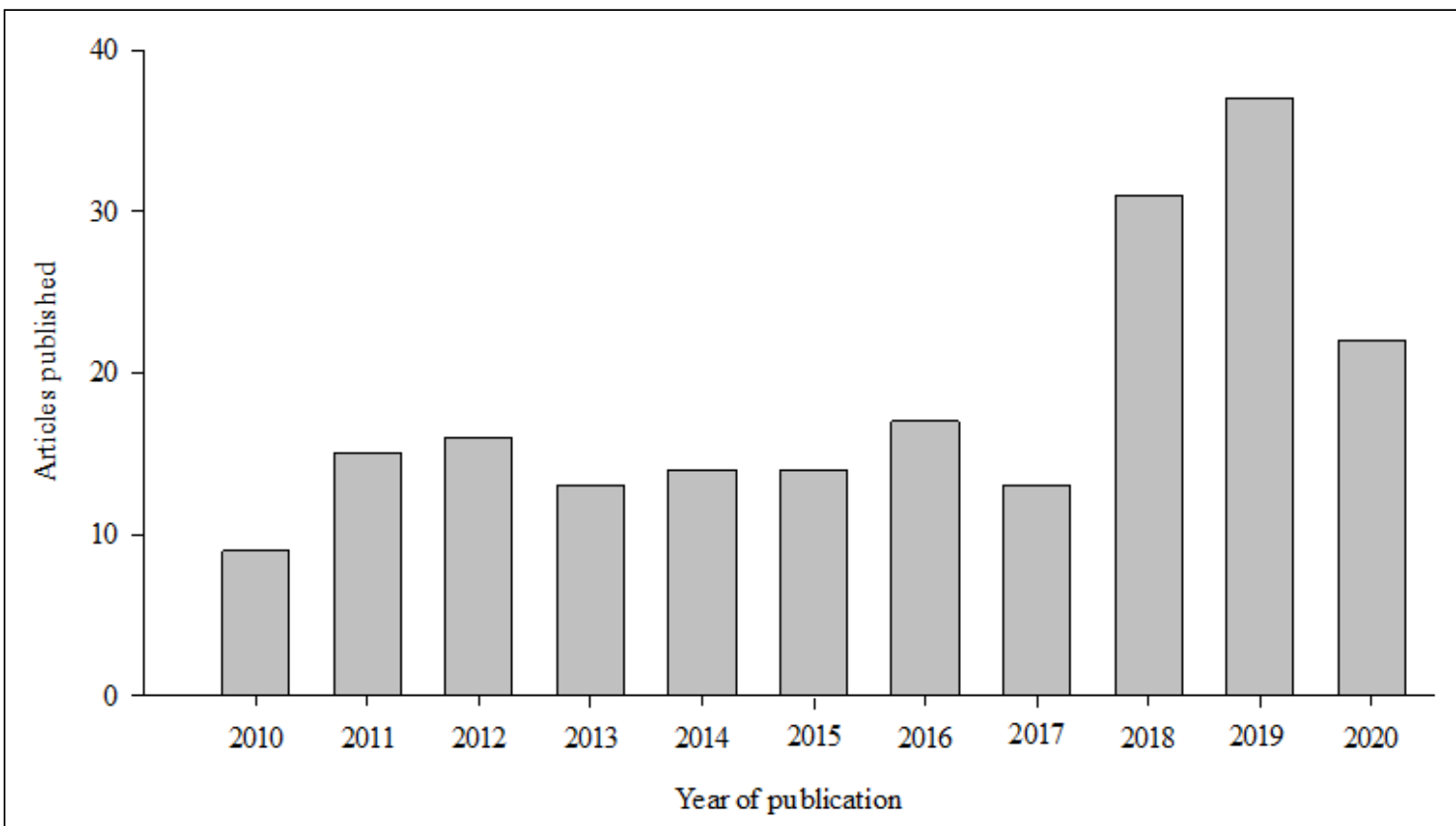

Figure 1 - Number of articles published on the use of plant extracts in agriculture and application in seeds between January 2010 and August 2020, indexed at the Web of Science.

demonstrating potential alternatives for application in production systems (KHAN et al., 2020; CONFORTIN et al., 2019).

A total of 133 journals were identified publishing articles on the use of plant extracts in agriculture, with Crop Protection presenting the highest frequency of publications, followed by the journals European Journal of Plant Pathology, Pakistan Journal of Botany and Semina-Ciências Agrárias (Figure 2).

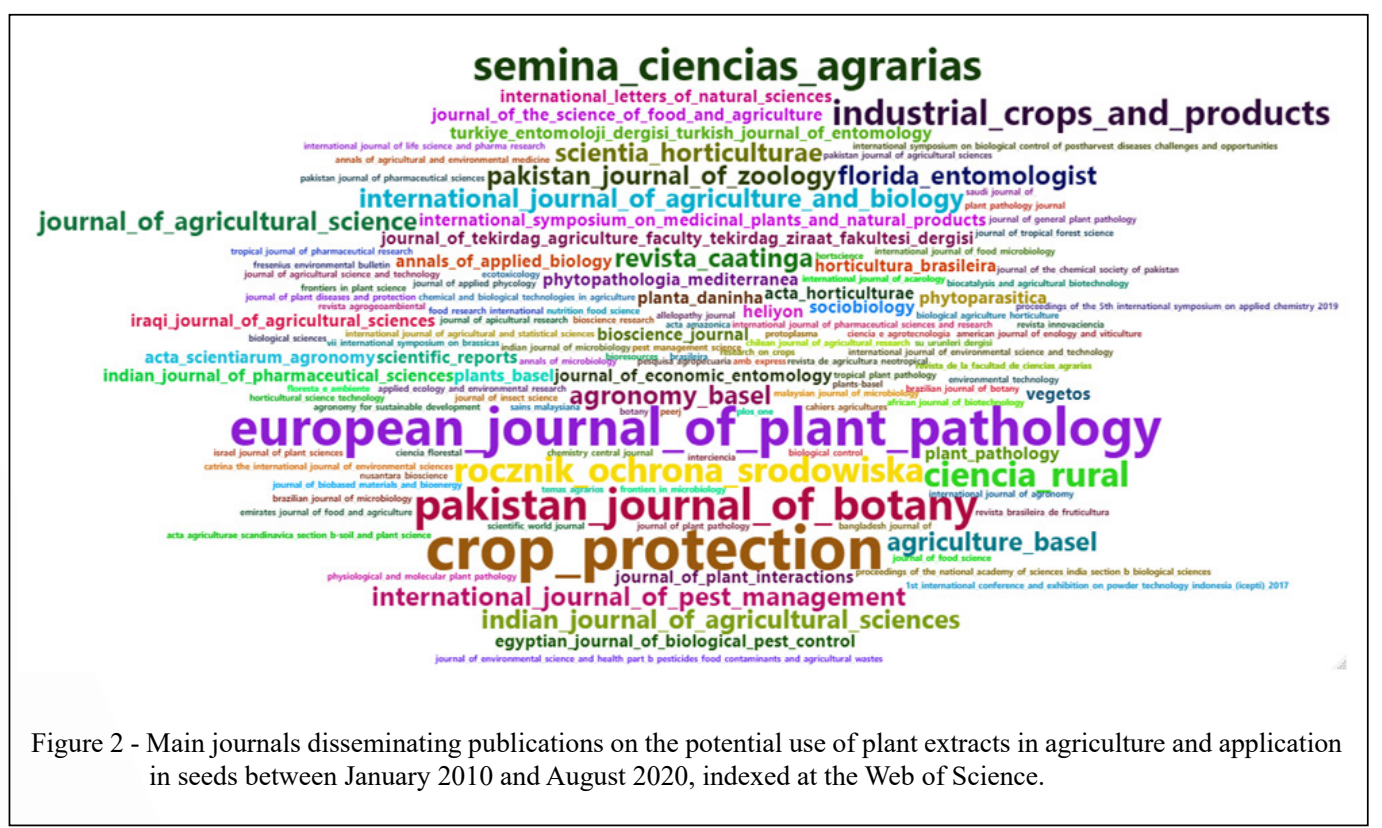

Ciência Rural, v.52, n.5, 2022. 
These journals present international impact and visibility; nevertheless, $13.9 \%$ were Brazilian journals and $86.06 \%$ were journals published in other countries. The national journals present major importance not only in the dissemination of national studies, since they connect a great number of studies generated and developed in other countries on the topic of plant extracts in agriculture and in the treatment of seeds.

It was observed that, among the countries which presented the greatest frequency of publications referring to the potentialities of the use of plant extracts in agriculture and application in seeds over the past ten years are Brazil (20.4\%), India (11.44\%) and Pakistan (9.4\%) (Figure 3A and 3B). In Latin America, Brazil leads the ranking of investments in agricultural research exactly for having a well-defined vocation and agricultural profile, with many Universities and Research Centers exclusively dedicated to scientific development in the field of Agrarian Sciences.

The Brazilian productive leadership is related, primarily, to technological aspects, but also to the edaphoclimatic characteristics and; especially, to the availability of production fields. Nonetheless, a great part of this production is still based on the use of pesticides (SOARES et al., 2019), boosting investments in research on alternative technologies and ecological strategies aimed at agriculture (PEREIRA et al., 2018).

Another relevant factor is that in Brazil, great part of food production is derived from family agriculture or of small rural producers, who in turn have also practiced an agroecological-based agriculture (PEREIRA et al., 2018), using alternative sources for the control and management of pests and diseases, including the use of plant extracts (BARBOSA et al., 2015).

A similar situation is observed in India and in Pakistan (LAKSHMEESHA et al., 2019; KHAN et al., 2020), with researches aiming the use of plant extracts in agriculture for the control of phytopathogenic organisms (MEENA et al., 2020), insects (ZAKA et al., 2019), treatment of seeds (ATRI \& TIWANA, 2019) and resistance induction (NARASIMHAMURTHY et al., 2019). Similar to what occurs in Brazil, family farming has great relevance in these two countries, making possible the use of alternative methods, such as plant extracts, for the management of the agroecosystem.

Considering the topic in agriculture, approximately $58.7 \%$ of the works explored the potential of plant extracts on phytopathogenic

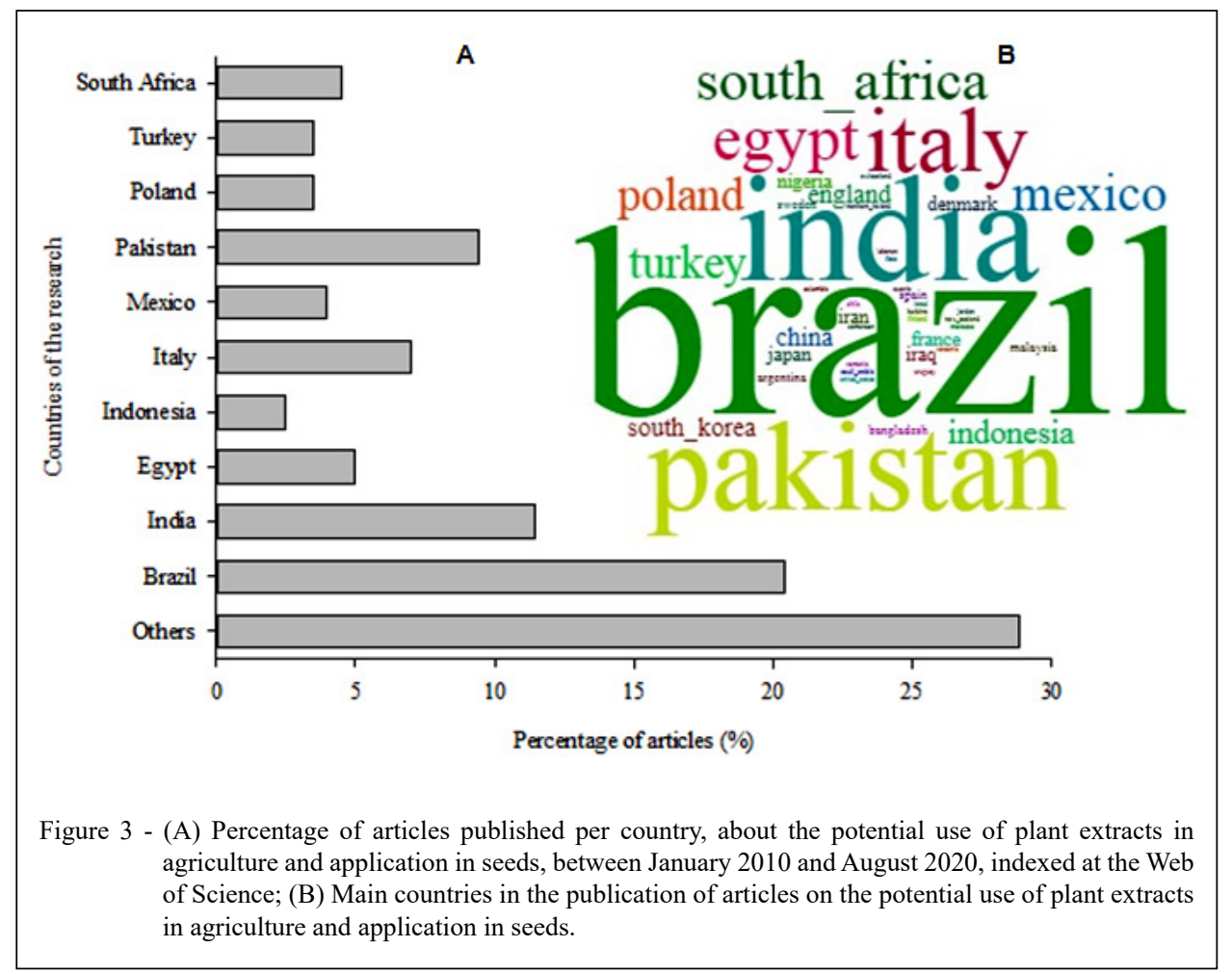

Ciência Rural, v.52, n.5, 2022. 
organisms, either in the control of diseases in plants, as the effects on the biology of fungi (SILVA et al., 2020), of bacteria (KARABÜYÜK \& AYSAN, 2019) or nematodes (SAHAYARAJ et al., 2018) (Figure $4 \mathrm{~A})$. Furthermore, it is observed that approximately $20 \%$ of the researches aimed the use for control, biology or repellency of insects (ZAKA et al., 2019; OJO et al., 2020), 12.43\% of the researches explored the biostimulant effect in plants (COZZOLINO et al., 2020; MOLA et al., 2019), demonstrating a potential use in agriculture still little explored.

Other two applications also discussed in some articles; although, in smaller volume, were the use of plant compounds as a triggering source of natural resistance-inducing genes against phytopathogenic organisms, resistance to insects and abiotic factors (6.46\%) (ALSAHLI et al., 2018) and herbicide or allelopathic effect on plant control (4.97\%) (FINDURA et al., 2020), especially in the management of spontaneous plants in horticulture (CASER et al., 2020).

Considering the application in agriculture, $34.84 \%$ of the studies evaluated the potential of the application directly in plants, being $23.9 \%$ under conditions in vivo and $10.9 \%$ under conditions in vivo and in vitro (Figure 4B). This evidenced the importance of understanding the direct application of plant compounds as potential alternative sources in agriculture for interactions plant/plant extracts and plant/plant extracts/phytopathogenic organisms. AL-MOHMADI and AL-ANI (2019) evaluated the effect of direct leaf application of licorice (Glycyrrhiza glabra L.) extract on the growth and productivity of grains of Sorghum cv. Rabih, and reported an increase in plant height and in the productivity of grains in the period of Spring and Fall, when the sorghum plants were sown at high density.

The potential of the direct application of plant compounds has also been explored in

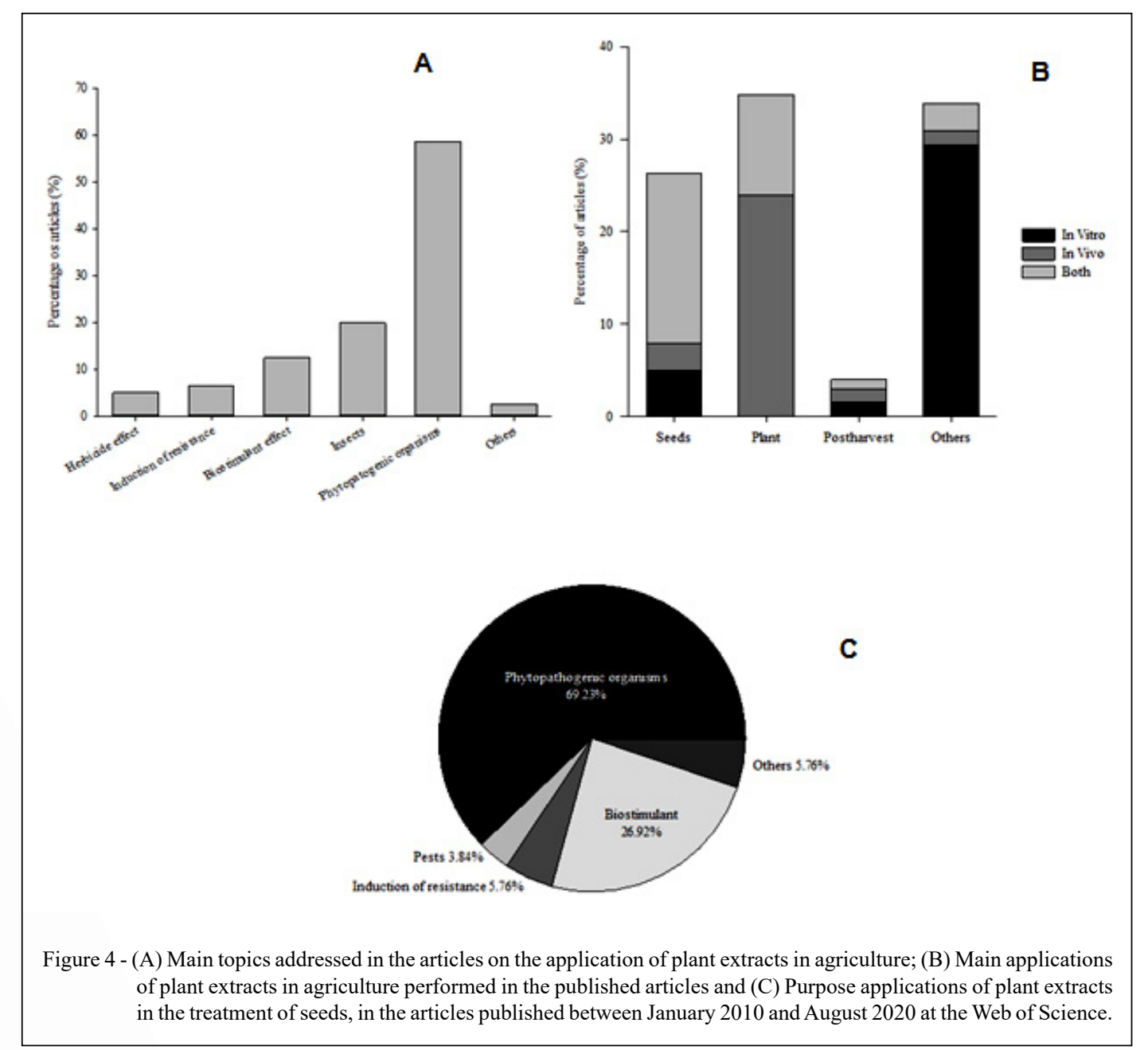

Ciência Rural, v.52, n.5, 2022. 
vegetables, such as, for instance, in the study of JANG and KUK (2019), who evaluated the effect on the growth of lettuce, broccoli, endive and kale subjected to leaf spraying of 31 plant extracts from agricultural materials. These authors verified an increment from 31 to $45 \%$ in the fresh weight of lettuce sprayed with aqueous extract of Allium tuberosum, aqueous extract of Glycine max (cvs. Daewon and Haepum) leaves, fermented, aqueous and ethanolic extract of soybean (cv. Daewon) stems at the concentration of $5 \%$ when compared to the application of urea at $0.6,0.8$ and $1 \%$. KARABÜYÜK \& AYSAN (2019) evaluated the effect of the treatment of seeds and the pulverization of tomato plants with twenty-nine plant extracts against the bacterial spot caused by Pseudomonas syringae pv.. Leaf pulverization at the concentration of $4.25 \mu \mathrm{l} / \mathrm{ml}$ of Allium sativum, Eucalyptus camaldulensis, Origanum onites and Zingiber officinale extracts reduced the incidence of the disease in $96-99 \%$ for all extracts, and when applied to the root, it was suppressed in $80-100 \%$ without promoting negative effects on the germination.

In a broader approach, SINGH et al. (2019) performed the treatment of seeds and plants of basmati rice with carbendazim, Trichoderma harzianum, Pseudomonas fluorescens and extract of Sesbania punicea (Cav.) Benth. against Meloidogyne graminicola, and verified that all treatments were efficient in the reduction of the population of nematodes; nevertheless, when applied in vivo, the extract of Sesbania increased the biomass of the rice plant in up to $68 \%$ in comparison with the other treatments. In addition to providing greater tolerance of the plant to $M$. graminicola, with a $37.7 \%$ reduction in the population of nematodes.

It is worth pointing out that, for other applications in agriculture, as well as for the topic in agriculture from the articles analyzed, there is a higher predominance of studies analyzing the direct effect in phytopathogenic organisms in vitro (OJO et al., 2020). Furthermore, 3.98\% of the researches evaluated the potential of application in the postharvest sector, especially as organic coating and treatment of fruits (KOLTZ et al., 2020; BOITEUX et al., 2019; HERNÁNDEZ-GUERRERO et al., 2020).

The application of plant extracts in the treatment of seeds is also highlighted with $26.86 \%$ of the total of published articles (Figure 4B). Of them, as in the studies of application in plants, more than $68.5 \%$ have been performed under conditions in vitro + in vivo, $10.76 \%$ in vivo and $18.5 \%$ under condition in vitro. Phytopathogenic organisms directly interfere in seed quality, affecting the initial development of seedlings and the final establishment of production fields (ROCHA et al., 2020). Additionally, great part of the diseases that occur in adult plants derived from causal agents associated with seeds, making preventive management extremely important. This is reflected on the highest percentage of articles with this purpose (69.29\%) among the total of researches that address the use of plant extracts in seeds (Figure 4C). Other applications of the plant extracts in seeds include the use as biostimulant $(26.92 \%)$, in resistance induction $(5.76 \%)$ and in pest control (3.84\%).

Regarding the management of fungi associated with the seeds, CHANDEL and KUMAR (2017) studied the effect of eleven plant extracts on rot fungi of storage Aspergiluss sp., and of field Alternaria alternata, A. solani, Phoma sp and Fusarium spp. and on the parameters of germination and vigor in pea (Pisum sativa) seeds and seedlings. The use of Vitex negundo and Melia azadiractha extracts at the concentration of $30 \%$ presented minimum rot of $1.94 \%$ compared to the untreated seeds $(13.84 \%)$, with maximum germination superior to $96.41 \%$ for extracts of Mentha piperata and Tagetes erecta.

Considering that the first signs of defense in the plants are triggered still in the seed, by the activation of preventive local and systemic defense mechanisms in plants against pathogens, ALSAHLI et al. (2018) verified higher enzyme activity of guaiacol peroxidase (POX), phenylalanine ammonia lyase (PAL) and genes coding for defense in sunflower plants after the treatment of seeds with Curcuma longa $\mathrm{L}$. extracts at the concentration of $10 \%$ against Fusarium solani. CHANDRASHEKHARA et al. (2010) verified significant increases in the parameters of quality and induction of resistance to mildew (Sclerospora graminicola [Sacc.] Schroe) in millet seeds (Pennisetum galaucum $\mathrm{R}$. Br.) subjected to the treatment with extracts of Azadirachta indica, Argemone mexicana, Commiphora caudata, Mentha piperita, Emblica officinales and Viscum album.

The occurrence of pests in seeds during storage is another factor of great relevance for the agricultural sector. OJO et al. (2020) evaluated the efficiency of root and stem extracts of Cleistopholis patens (Benth) in the protection of cowpea seeds against infestation by Callosobruchus maculatus during storage and they reported mortality of $77.05 \%$ of the insects for a dose of $5 \%$ in a period of 24 hours after application for stem extract, at the same time that there were 50 and $95 \%$ of mortality of the insects subjected to root extract, as well as a reduction in oviposition and emergence of adults, at the same concentration. 
Considering the various applications that have been explored in the studies with plant extracts, the use in the treatment of agricultural soils and potential natural sources of nitrification inhibitors can also be highlighted (MUÑOZ et al., 2014).

Among the main species and genera of plants used with potentialities of application in agriculture and in the treatment of seeds, Azadirachta indica A. Juss. (11.94\%), Allium sativum L. (7.46\%) and Eucalyptus sp. (4.97\%) were the most frequently studied (Table 1).

The genera Acacia sp., Brassica sp. and the species Melia azedarach L., Rosmarinus officinalis L. and Zingiber officinale R. were identified in $2.48 \%$

Table 1 - Main species/genera used in studies on the potential of application of plant extracts in agriculture and in the treatment of seeds, in the articles published between January 4th 2010 and August 2020 at the Web of Science.

\begin{tabular}{|c|c|c|c|}
\hline Specie/genera & Application in agriculture & Frequency $(\%)$ & References \\
\hline
\end{tabular}
al., 2014.

\begin{tabular}{|c|c|c|c|}
\hline Allium sativum $\mathrm{L}$. & $\begin{array}{l}\text { Phytopathogenic } \\
\text { organisms; insects. }\end{array}$ & 7.96 & $\begin{array}{l}\text { BOULOGNE et al., 2012; KARABUYUK; AYSAN, 2019; } \\
\text { CHAND et al., 2016; KARABUYUK; AYSAN, 2018; } \\
\text { SALJOQI et al., 2012; MAHMUD; HOSSAIN, 2017; } \\
\text { MANGWENDE; KRITZINGER; AVELING, 2019; SINGH; } \\
\text { et al, 2013; MUTHUKUMAR et al., 2010; UMARUSMAN; } \\
\text { AYSAN; OZGUVEN, 2019; SHIFA; GOPALAKRISHNAN; } \\
\text { VELAZHAHAN, 2018; RUIZ-COUTINO et al., 2019; LIMA } \\
\text { et al., 2016; VIOLETH; HERRERA; Garcia, 2018; GOYAL; } \\
\text { SHARMA, 2012; SAS-PIOTROWSKA; PIOTROWSKI, } \\
2011 .\end{array}$ \\
\hline Eucalyptus sp. & $\begin{array}{l}\text { Phytopathogenic } \\
\text { organisms; insects; } \\
\text { herbicide effect; others. }\end{array}$ & 4.97 & $\begin{array}{l}\text { HAMADET al., 2019; KARABUYUK; AYSAN, 2019; } \\
\text { KARABUYUK; AYSAN, 2018; SILVA; ANDRADE; } \\
\text { BETTIOL., 2020; SHAPIRO-ILAN et al., 2013; KHAN et } \\
\text { al., 2020; MUNOZ; QUILODRAN; NAVIA, 2014. }\end{array}$ \\
\hline $\begin{array}{l}\text { Syzygium aromaticum } \\
\text { (L.) Merr. \& L. M. } \\
\text { Perry }\end{array}$ & $\begin{array}{c}\text { Phytopathogenic } \\
\text { organisms; others; insects. }\end{array}$ & 3.98 & $\begin{array}{l}\text { HAMAD et al., 2019; SILVA et al., 2014; LAKSHMEESHA } \\
\text { et al., 2019; CARMELLO; CARDOSO, 2018; } \\
\text { UMARUSMAN; AYSAN; OZGUVEN, 2019; RUIZ- } \\
\text { COUTIÑO et al., 2019; MASANGWA; AVELING; } \\
\text { KRITZINGER, 2013; ZAKA et al., 2019. }\end{array}$ \\
\hline Curcuma longa $\mathrm{L}$. & $\begin{array}{l}\text { Phytopathogenic } \\
\text { organisms; biostimulant } \\
\text { effect; insects; resistance } \\
\text { induction. }\end{array}$ & 3.98 & $\begin{array}{l}\text { MAMARABADI; TANHAEIAN; RAMEZANY, 2018; } \\
\text { CHAND et al., 2016; TANVEER et al., 2016; SALJOQI et } \\
\text { al., 2012; SIDDIQUE et al., 2019; ALSAHLI et al., 2018; } \\
\text { HAN et al., 2018; FU et al., 2018. }\end{array}$ \\
\hline $\begin{array}{l}\text { Cymbopogon citratus } \\
\text { (D.C.) } \\
\text { Stapf. }\end{array}$ & $\begin{array}{l}\text { Herbicide effect; } \\
\text { phytopathogenic } \\
\text { organisms; resistance } \\
\text { induction; insects; mites. }\end{array}$ & 3.48 & $\begin{array}{l}\text { SILVEIRA et al., 2010; CHAND et al., 2016; PEREIRA et } \\
\text { al., 2012; REHMAN et al., 2019; NGUEFACK et al., 2013; } \\
\text { VICENTINI et al., 2015; MANDIRIZA; KRITZINGER; } \\
\text { AVELI, 2018. }\end{array}$ \\
\hline Lippia sp. & $\begin{array}{l}\text { Herbicide effect; insects; } \\
\text { phytopathogenic } \\
\text { organisms. }\end{array}$ & 3.48 & $\begin{array}{l}\text { SILVEIRA et al., 2010; PHAMBALA et al., 2020; } \\
\text { PODEROSO et al., 2016; RODRIGUEZ et al., 2011; } \\
\text { MONTEIRO et al., 2014; TEMBO et al., 2018; FEREIRA et } \\
\text { al., } 2014 \text {. }\end{array}$ \\
\hline Acacia sp. & $\begin{array}{l}\text { Phytopathogenic } \\
\text { organisms; biostimulant } \\
\text { effect. }\end{array}$ & 2.49 & $\begin{array}{l}\text { BAKA; RASHAD, 2016; TANVEER et al., 2016; HUSSAIN } \\
\text { et al., 2017; HASSAN et al., 2013; RAFI; DAWAR; ZAKI, } \\
2015 \text {. }\end{array}$ \\
\hline
\end{tabular}

Ciência Rural, v.52, n.5, 2022. 
of the analyzed researches (Table 1 and 2), whereas the genera Citrus sp., Piper sp., Capsicum sp., Cinnamomum sp. and the species Punica granatum L., Ocimum basilicum L., Nicotiana tabacum L. and Carica papaya L. were represented in $1.99 \%$ of the studies with applications in agriculture and in the treatments of seeds (Table 2).

The data indicated an increasing trend in the search for more sustainable strategies and with potential application in agriculture for different purposes, especially in the treatment of seeds. Among these strategies, plant extracts are indicated as viable alternatives to conventional treatments, promoting the rise in quality and reduction in the costs of the agricultural cultivations, minimizing the impacts in the ecosystems. Furthermore, it is important to highlight that the proper use of plant extracts will depend on the methodology for making the extracts, the use of appropriate concentration and the number of applications for each expected objective.

\section{CONCLUSION}

The use of plant extracts in agriculture has a potential, demonstrated by the high number of publications, especially in the years 2018, 2019 and 2020, with Brazil being the country with the highest production of research directed to this field of study. Control of phytopathogenic organisms, effect in insects, biostimulant effect, induction of

Table 2 - Species/genera used in studies on the potential of application of plant extracts in agriculture and in the treatment of seeds, in the articles published between January 4th 2010 and August 2020 at the Web of Science.

\begin{tabular}{|c|c|c|c|}
\hline Specie/genera & Application in agriculture & Frequency $(\%)$ & References \\
\hline Melia azedarach $\mathrm{L}$. & $\begin{array}{l}\text { Phytopathogenic organisms; } \\
\text { insects; mites; biostimulant } \\
\text { effect. }\end{array}$ & 2.48 & $\begin{array}{l}\text { SILVA et al., 2014; MEFTAH ET AL., 2011; ROY; } \\
\text { MUKHOPADHYAY, 2012; ATRI; TIWANA, 2019; } \\
\text { ARSHAD ET AL., } 2019 .\end{array}$ \\
\hline Brassica $\mathrm{sp}$. & $\begin{array}{l}\text { Phytopathogenic organisms; } \\
\text { biostimulant effect. }\end{array}$ & 2.48 & $\begin{array}{c}\text { KOLTZ et al., 2020; MASHELA; POFU; NZANZA, } \\
\text { 2013; HASSAN et al., 2013; MONTEIRO et al., } \\
\text { 2014; SZPARAGA; KOCIRA, } 2018 .\end{array}$ \\
\hline Rosmarinus officinalis L. & $\begin{array}{l}\text { Phytopathogenic organisms; } \\
\text { insects; others. }\end{array}$ & 2.48 & $\begin{array}{l}\text { MENGULLOUGLU; SOYLU, 2012; } \\
\text { DELLAVALLE et al., 2011; RAMOS et al., 2019; } \\
\text { KARAASLAN, 2018; MUELLER et al., } 2016 .\end{array}$ \\
\hline Zingiber officinale $\mathrm{R}$. & $\begin{array}{l}\text { Phytopathogenic organisms; } \\
\text { resistance induction. }\end{array}$ & 2.48 & $\begin{array}{l}\text { KARABUYUK; AYSAN, 2019; BHUTIA et al., } \\
\text { 2016; COSTA et al., 2019; MANGWENDE; } \\
\text { KRITZINGER; AVELING, 2019; ANDAYANIE et } \\
\text { al., } 2019 .\end{array}$ \\
\hline Carica papaya $\mathrm{L}$. & $\begin{array}{l}\text { Phytopathogenic organisms; } \\
\text { insects. }\end{array}$ & 1.99 & $\begin{array}{c}\text { MASANGWA; KRITZINGER; AVELING, 2017; } \\
\text { HERNANDEZ-GUERRERO et al., 2020; } \\
\text { FIGUEROA-BRITO et al., 2011; MASANGWA; } \\
\text { AVELING; KRITZINGER, } 2013 .\end{array}$ \\
\hline Nicotiana tabacum L. & Insects; others. & 1.99 & $\begin{array}{l}\text { BOULOGNE et al., 2012; PHAMBALA et al., 2020; } \\
\text { RUIZ-COUTIÑO et al., 2019; PEREIRA et al., } 2020 .\end{array}$ \\
\hline Citrus sp. & $\begin{array}{l}\text { Insects; biostimulant effect; } \\
\text { phytopathogenic organisms. }\end{array}$ & 1.99 & $\begin{array}{l}\text { SHAPIRO-ILAN et al., 2013; MAHAKHAM et al., } \\
\text { 2017; LIMA et al., 2016; ZAKA et al., } 2019 .\end{array}$ \\
\hline Ocimum basilicum L. & Phytopathogenic organisms. & 1.99 & $\begin{array}{l}\text { HAMADET al., 2019; HUSSAIN et al., 2015; IRAM } \\
\text { et al., 2018; AHMED et al., } 2010 .\end{array}$ \\
\hline Piper sp. & Insects; herbicide effect. & 1.99 & $\begin{array}{l}\text { BALDIN et al., 2015; JALEEL et al., 2020; } \\
\text { MENDOZA; CELIS; PACHON, 2014; HARA; } \\
\text { SZPARAGA; CZERWINSKA, } 2018 .\end{array}$ \\
\hline Capsicum sp. & $\begin{array}{l}\text { Insects; phytopathogenic } \\
\text { organisms; others. }\end{array}$ & 1.99 & $\begin{array}{l}\text { SALJOQI et al., 2012; MEFTAH; BOUGHDAD; } \\
\text { BOUCHELTA, 2011; Al-SAMARRAI; SINGH; } \\
\text { SYARHABIL, 2012; RUIZ-COUTIÑO et al., } 2019 .\end{array}$ \\
\hline Cinnamomum sp. & $\begin{array}{l}\text { Phytopathogenic organisms; } \\
\text { biostimulant effect; others. }\end{array}$ & 1.99 & $\begin{array}{c}\text { JANG; KIM; KUK, 2019; CARMELLO; } \\
\text { CARDOSO, 2018; FLAVIO et al., 2014; RUIZ- } \\
\text { COUTIÑO et al., } 2019 .\end{array}$ \\
\hline Punica granatum L. & $\begin{array}{l}\text { Insects; phytopathogenic } \\
\text { organisms; resistance } \\
\text { induction. }\end{array}$ & 1.99 & $\begin{array}{l}\text { POTRICH et al., 2020; QUATTRUCC et al., 2013; } \\
\text { Tayel et al., 2016; PANGALLO et al., } 2017 .\end{array}$ \\
\hline
\end{tabular}


resistance and herbicide effect have been the main topics explored for use in agriculture. The direct application of plant extracts is mainly centered in plants and seeds and, for the application in seeds, the focus is the control of phytopathogenic organisms and biostimulant effect.

\section{ACKNOWLEDGEMENTS}

The present research was performed with support of the Coordenação de Aperfeiçoamento de Pessoal de Nível Superior - Brazil (CAPES)- Finance Code 001

\section{DECLARATION OF CONFLICT OF} INTEREST

The authors declare there is no conflict of interest. The funders did not have any role in the design of the study; in the collection, analysis or interpretation of the data; in the writing of the manuscript and in the decision of publishing the results.

\section{AUTHORS' CONTRIBUTIONS}

All authors have contributed equally to the design and writing of the manuscript.

All authors have critically revised the manuscript and approved the final version.

\section{REFERENCES}

AHMED, S. S et al. Environmental impact of the use of some eco-friendly natural fungicides to resist rust disease in wheat. CATRINA, 2019,18, 87-95. Available from: $<$ https://cat.journals. ekb.eg/article 28611.html>. Accessed: Oct. 12, 2020. doi: 10.21608/CAT.2019.28611

AL_SAMARRAI, G et al. Evaluating eco-friendly botanicals (natural plant extracts) as alternatives to synthetic fungicides Annals of Agricultural and Environmental Medicine., vol.19, no.4, 2012, pp.673-676. Available from: <http://www.aaem.pl/Evaluatingeco-friendly-botanicals-natural-plant-extracts-as-alternatives-tosynthetic,71842,0,2.html>. Accessed: Oct. 12, 2020

AL-MOHMADI, S. Y. A.; AL-ANI, M. H. I. Effect of spraying with different concentration of licorice extract and plant densities in growth and yield of sorghum bicolor 1. Iraqi Journal of Agricultural sciences, [s.1.], v.50, n.6, p.1478-1485, 2019. Available from: <https://doi.org/10.36103/ijas.v50i6.835> Accessed: Oct. 09, 2020. doi: 10.36103/ijas.v50i6.835.

ALSAHLI, A. A. et al. Extract from Curcuma longa L. triggers the sunflower immune system and induces defence-related genes against Fusarium root rot. Phytopathologia Mediterranea, [s.1.], v.57, n.1, p.26-36, 2018. Available from:: <https://doi. org/10.14601/Phytopathol_Mediterr-21176>. Accessed: Oct. 09, 2020. doi: 10.14601/Phytopathol Mediterr-21176.

AL-SAMARRAI G.; SINGH H.; SYARHABIL M. Evaluating eco-friendly botanicals (natural plant extracts) as alternatives to synthetic fungicides. Annals of Agricultural and Environmental Medicine, 2012. Available from: $<$ https://appswebofknowledge.ez31.periodicos.capes.gov.br/full record. do product $=$ WOS\&search $\_$mode $=$GeneralSearch\&qid $=51 \& S I D=5 \mathrm{~A}$ bywt7biRrWYsWud3J\&page=1\&doc=1>. Accessed: Oct. 12, 2020.

ANDAYANIE, W. $\mathrm{R}$ et al. The plant defence inducer activity of Anacardium occidentale Linn., Azadiracta indica A. Juss. and Zingiber officinale Rosc. extracts against Cowpea mild mottle virus infecting soybean. Proceedings of the 5th International Symposium on Applied Chemistry 2019, 2019. Available from: $<$ https://doi.org/10.1063/1.5134597>. Accessed: Oct. 12, 2020 doi: $10.1063 / 1.5134597$.

ARSHAD, M. et al. Field evaluation of water plant extracts on sucking insect pests and their associated predators in transgenic $\mathrm{Bt}$ cotton. Egyptian Journal of Biological Pest Control, [s.1.], v.29, n.1, 2019. Available from: $<$ https://doi.org/10.1186/s41938-019-0142-8>. Accessed: Oct. 12, 2020. doi: 10.1186/s41938-019-0142-8.

ATRI, A.; TIWANA, U. S. Effect of seed treatment and foliar spray on leaf blight of fodder oat in Punjab. Phytoparasitica, 47, 723-731, 2019. Available from: <https://doi.org/10.1007/s12600-019-007587>. Accessed: Oct. 12, 2020. doi: 10.1007/s12600-019-00758-7.

BAKA, Z. A. M.; RASHAD, Y. M. Alternative control of early blight of tomato using plant extracts from Acacia nilotica, Achillea fragrantissima and Calotropis procera. Phytopathologia Mediterranea, vol.55, no.1, pp.121-129, 2016. Available from: $\quad<$ https://doi.org/10.14601/Phytopathol Mediterr-17161>. Accessed: Oct. 12, 2020. doi: 10.14601/Phytopathol Mediterr-17161.

BALDIN, E. L et al. Botanical extracts: alternative control for silverleaf whitefly management in tomato extratos botânicos. Horticultura Brasileira, [S.L.], v.33, n.1, p.5965 , 2015. Available from: <http://dx.doi.org/10.1590/s0102053620150000100010>. Accessed: Oct. 12, 2020. doi: 10.1590/ s0102-053620150000100010.

BARBOSA, W. F et al. Pesticides and reduced-risk insecticides, native bees and pantropical stingless bees: Pitfalls and perspectives. Pest Management Science, [s.1.], v.71, n.8, p.1049-1053, 2015. Available from: $<$ https://doi.org/10.1002/ps.4025>. Accessed: Oct. 12, 2020. doi: $10.1002 /$ ps.4025.

BHUTIA, D. D et al. Antifungal activity of plant extracts against Colletotrichum musae, the post harvest anthracnose pathogen of banana cv. Martaman. Nutrition \& Food Science, 2016. Available from: <https://doi.org/10.1108/NFS-06-20150068>. Accessed: Oct. 12, 2020. doi: 10.1108/NFS-06-2015-0068.

BOITEUX, J. et al. ECo-friendly postharvest protection: Larrea cuneifolia-nades extract against Botrytis cinerea. Revista de la Facultad de Ciencias Agrarias UNCuyo, 51(2), 427-437, 2019. Available from: <http://revistas.uncuyo.edu.ar/ojs/index.php/ RFCA/article/view/2729>. Accessed: Oct. 12, 2020.

BOULOGNE, I et al. Acromyrmex octospinosus (Hymenoptera: Formicidae) management: effects of TRAMILs fungicidal plant extracts. Journal of Economic Entomology, 2012. Available from: <https://doi.org/10.1603/EC11313>. Accessed: Oct. 12, 2020. doi: 10.1603/ec11313. PMID: 22928301.

BOULOGNE, I et al. Acromyrmex octospinosus (Hymenoptera: formicidae) management. part 1. Pest Management Science, [S.L.], v.68, n.2, p.313-320, 19. 2011. Available from: <http:// dx.doi.org/10.1002/ps.2267>. Accessed: Oct. 12, 2020. doi: $10.1002 /$ ps.2267. 
CARMELLO, C. R.; CARDOSO, J. C. Effects of plant extracts and sodium hypochlorite on lettuce germination and inhibition of Cercospora longissima in vitro. Scientia Horticulturae, [S.L.], v.234, p.245-249, 2018. Available from: <http://dx.doi org/10.1016/j.scienta.2018.02.056>. Accessed: Oct. 12, 2020. doi: 10.1016/j.scienta.2018.02.056

CASER, M. et al. Activity of Ailanthus altissima (Mill.) swingle extract as a potential bioherbicide for sustainable weed management in horticulture. Agronomy, [s.1.], v.10, n.7, p.965, 2020. Available from: <https://doi.org/10.3390/agronomy10070965>. Accessed: Oct. 12, 2020. doi: 10.3390/agronomy 10070965 .

CHAND, $\mathrm{S}$ et al. Antifungal efficacy of botanicals against seed borne fungal plant pathogens of basmati rice. 12. 169-175. International Journal of Agricultural and Statistical Sciences, 2016. Available from: <http://www.connectjournals.com/file_full_ text/2579101H_169-175.pdf>. Accessed: Oct. 12, 2020.

CHANDEL, S.; KUMAR, V. Effect of plant extracts as prestorage seed treatment on storage fungi, germination percentage and seedling vigour of pea (Pisum sativum). Indian Journal of Agricultural Sciences, [s.1.], v.87, n.11, p.1476-1481, 2017. Available from: <http://epubs.icar.org.in/.../75703>. Accessed: Oct. 12, 2020. ISSN: 00195022.

CHANDRASHEKHARA et al. Seed treatment with aqueous extract of Viscum album induces resistance to pearl millet downy mildew pathogen. Journal of Plant Interactions, [s.1.], v.5, n.4, p.283-291, 2010. Available from: <https://doi. org/10.1080/17429140903556539>. Accessed: Oct. 12, 2020. doi: $10.1080 / 17429140903556539$

COLTRO-RONCATO, S. et al. Nematicidal activity of crambe extracts on Meloidogyne spp. Semina: Ciências Agrarias, [s.l.], v.37, n.4, p.1857-1870, 2016. ISSN: 16790359. Available from: <http://dx.doi.org/10.5433/1679-0359.2016v37n4p1857>. Accessed: Oct. 12, 2020. doi: 10.5433/1679-0359.2016v37n $4 \mathrm{p} 1857$.

CONFORTIN, T. C. et al. Extracts from Lupinus albescens: antioxidant power and antifungal activity in vitro against phytopathogenic fungi. Environmental Technology (United Kingdom), [s.1.], v.40, n.13, p.1668-1675, 2019. Available from: $<$ https://doi.org/10.1080/09593330.2018.1427800>. Accessed: Oct. 12, 2020. doi: 10.1080/09593330.2018.1427800.

COSTA, A. P. et al. Aquosous extract and essential oil of ginger induce biochemical defense mechanisms in bean. Journal of Neotropical Agriculture, [s.1.], v.6, n.2, p.79-86, 2019. Available from: $<10.32404 /$ rean.v6i2.2721 $>$. Accessed: Oct. 12, 2020. doi: 10.32404/rean.v6i2.2721

COZZOLINO, E. et al. Appraisal of biodegradable mulching films and vegetal-derived biostimulant application as eco-sustainable practices for enhancing lettuce crop performance and nutritive value. Agronomy, [s.1.], v.10, n.3, 2020. Available from: $<$ https:// doi.org/10.3390/agronomy10030427>. Accessed: Oct. 12, 2020. doi: 10.3390/agronomy10030427.

DELLAVALLE, P. D et al. Antifungal activity of medicinal plant extracts against phytopathogenic fungus Alternaria spp. Chilean Journal of Agricultural Research, [S.L.], v.71, n.2, p.231239, 2011. Available from: <http://dx.doi.org/10.4067/s0718 58392011000200008>. Accessed: Oct. 12, 2020. doi: 10.4067/ s0718-58392011000200008.
EZEONU, C.S et al. Antifungal effect of aqueous and ethanolic extracts of neem leaves, stem bark and seeds on fungal rot diseases of yam and cocoyam. Chemical and Biological Technologies in Agriculture, v.5, 18, 2018. Available from: <https://doi. org/10.1186/s40538-018-0130-3>. Accessed: Oct. 12, 2020. doi: 10.1186/s40538-018-0130-3.

FERREIRA, E. F et al. Use of plant extracts on control in vitro of Colletotrichum gloeosporioides Penz. collected in papaya fruits (Carica papaya L.). Revista Brasileira de Fruticultura 36, 346352. 2014. Available from: <http://dx.doi.org/10.1590/0100-2945223/13>. Accessed: Oct. 12, 2020. doi: 10.1590/0100-2945-223/13.

FIAZ, M et al. Efficacy of plant extracts on some cotton (Gossypium hirsutum) pests: Amrasca bigutulla bigutulla Ishida and Thrips tabaci Lindeman. Pakistan Journal of Zoology, 44: 277-283. 2012. Available from: <https://www.zsp.com.pk/pdf44/277283\%20 36 \%20PJZ-520-10\%20Revised\%20copy\%20as\%20 per\%20recomendations.pdf $>$. Accessed: Oct. 12, 2020.

FIGUEROA BRITO, R et al. Insecticidal activity of seed extracts of Carica papaya (L.) against the fall armyworm Spodoptera frugiperda (JE Smith) (Lepidoptera: Noctuidae). Interciencia, 2011. Available from: <https://www.redalyc.org/articulo. oa? $\mathrm{id}=33921449008>$. Accessed: Oct. 12, 2020.

FINDURA, P.. et al. Evaluation of the effects of allelopathic aqueous plant extracts, as potential preparations for seed dressing, on the modulation of cauliflower seed germination. Agriculture, [s.1.], v.10, n.4, 2020. Available from: <https://doi.org/10.3390/ agriculture10040122>. Accessed: Oct. 12, 2020. doi: 10.3390/ agriculture 10040122 .

FLÁVIO, N. S. D. S et al. Health and physiological quality of sorghum seeds treated with aqueous extracts and essential oils. Semina: Ciências Agrárias, [S.L.], v.35, n.1, p.7, 26, 2014. Universidade Estadual de Londrina. Available from: $<\mathrm{http}: / / \mathrm{dx}$.doi. org/10.5433/1679-0359.2014v35n1p7>. Accessed: Oct. 12, 2020. doi: $10.5433 / 1679-0359.2014 \mathrm{v} 35 \mathrm{n} 1 \mathrm{p} 7$.

FREIRE, M. S.; SANTOS, C. D. G. Reaction of plant species to Meloidogyne enterolobii and the efficiency of their aqueous extracts in controlling the pathogen. Semina: Ciências Agrárias, [S.L.], v.39, n.6, p.2385, 30 nov. 2018. Available from: <http:/ dx.doi.org/10.5433/1679-0359.2018v39n6p2385>. Accessed: Oct. 12, 2020. doi: 10.5433/1679-0359.2018v39n6p2385.

$\mathrm{FU}, \mathrm{W}$. J et al. Isolation, purification and identification of the active compound of turmeric and its potential application to control cucumber powdery mildew. The Journal of Agricultural Science, [S.L.], v.156, n.3, p.358-366, 2018. Available from: $<$ http://dx.doi. org/10.1017/s0021859618000345 $>$. Accessed: Oct. 12, 2020. doi: $10.1017 / \mathrm{s} 0021859618000345$.

GARCIA, A. S.G et al. Can exposure to neem oil affect the spermatogenesis of predator Ceraeochrysa claveri? Protoplasma, 2019. Available from: <https://doi.org/10.1007/s00709-018-13297>. Accessed: Oct. 12, 2020. doi: 10.1007/s00709-018-1329-7.

GOYAL, S. K; SHARMA, P. Resistance sources and efficacy of botanicals and bio-agents against Downy mildew (Peronospora trigonella) of Fenugreek (Trigonella foenum graecum L.). Vegetos. 2012. Available from: <https://www.scitechnol.com/abstract/ resistance-sources-and-efficacy-of-botanicals-and-bioagentsagainst-downy-mildew-peronospora-trigonella-of-fenugreektrigonella-fo-4267.html >. Accessed: Oct. 12, 2020. 
HAMAD, Y. K et al. Activity of plant extracts/essential oils against three plant pathogenic fungi and mosquito larvae: GC/MS analysis of bioactive compounds. BioResources, 2019. Available from: $<$ https://bioresources.cnr.ncsu.edu/wp-content/uploads/2019/04/ bIOrES_14_2_4489_Hamad_ASASZ_Activity_Plant-Extracts Pathogenic_Fungi_Mosquito_Larvae_15512-1.pdf $>$. Accessed: Oct. $12,20 \overline{2}$. doi: $10.15376 /$ biores. $14.2 .4489-4511$.

HAN, J. W et al. In vivo assessment of plant extracts for control of plant diseases: a sesquiterpene ketolactone isolated from Curcuma zedoaria suppresses wheat leaf rust. Journal of Environmental Science and Health, Part B, [S.L.], v.53, n.2, p.135-140, 27, 2018. Available from: $<\mathrm{http}$ ://dx.doi.org/10 $.1080 / 03601234.2017 .1397448>$. Accessed: Oct. 12, 2020. doi 10.1080/03601234.2017.1397448.

HARA, P.; SZPARAGA, A. Ecological methods used to control fungi that cause diseases of the crop plant. Rocznik Ochrona Srodowiska. 2018. Available from: <https://apps-webofknowledge. ez31.periodicos.capes.gov.br/full record.do?product=WOS\&search 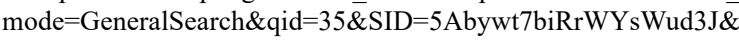 page $=1 \&$ doc $=2>$. Accessed: Oct. 12, 2020 .

HASSAN, M. A et al. Nematicidal effects of Acacia nilotica, Azadirachtaindica, Brassica chinensis and Ecklonia maxima against soybean cysts nematode. International Journal of Agriculture and Biology. 15. 599-602. 2013. Available from: <https://agris. fao.org/agris-search/search.do?recordID=PK2013000740> Accessed: Oct. 12, 2020. ISSN: 1560-8530.

HERNÁNDEZ-GUERRERO, S. E et al. Identification of fungal pathogens of mango and soursop fruits using morphological and molecular tools and their control using papaya and soursop leaf and seed extracts. International Journal of Agronomy, 2020. Available from: <http://dx.doi.org/10.1155/2020/8962328>. Accessed: Oct. 12, 2020. doi: 10.1155/2020/8962328.

HERNÁNDEZ-GUERRERO, S. E. et al. Identification of fungal pathogens of mango and soursop fruits using morphological and molecular tools and their control using papaya and soursop leaf and seed extracts. International Journal of Agronomy, [s.1.], v.2020, 2020. Available from: <https://doi.org/10.1155/2020/8962328>. Accessed: Oct. 12, 2020. doi: 10.1155/2020/8962328.

HUSSAIN, F et al. Anti-fungal activity of some medicinal plants on different pathogenic fungi. Pakistan Journal of Botany, 2015. Available from: <http://www.pakbs.org/pjbot/PDFs/47(5)/48. pdf $>$. Accessed: Oct. 12, 2020.

IRAM, W et al. Isolation of stored maize mycoflora, identification of aflatoxigenic fungi and its inhibition using medicinal plant extracts. International Journal of Agriculture \& Biology, 2018. Available from: <http://www.fspublishers.org/published papers/22438.pdf>. Accessed: Oct. 12, 2020. doi: 10.17957/ IJAB/15.0749.

JALEEL W, et al. Evaluating the repellent effect of four botanicals against two Bactrocera species on mangoes. PEERJ 8. 2020. Available from: <https://doi.org/10.7717/peerj.8537>. Accessed: Oct. 12 , 2020. doi: $10.7717 /$ peerj. 8537 .

JANG, S. J; KUK, Y. I. Growth promotion effects of plant extracts on various leafy vegetable crops. Horticultural Science and Technology, [s.1.], v.37, n.3, p.322-336, 2019. Available from: $<$ https://doi.org/10.7235/HORT.20190033>. Accessed: Oct. 12, 2020. doi: 10.7235/HORT.20190033.
$\mathrm{KAAB}$, S. B. et al. Screening of Tunisian plant extracts for herbicidal activity and formulation of a bioherbicide based on Cynara cardunculus. South African Journal of Botany, [s.1.], v.128, p.67-76, 2020. Available from: <https://doi.org/10.1016/j. sajb.2019.10.018>. Accessed: Oct. 12, 2020. doi: 10.1016/j. sajb.2019.10.018.

KAMRAN, M. et al. Effect of plant extracted smoke and reversion of abscisic acid stress on lettuce. Pakistan Journal of Botany, [s.1.], v.45, n.5, p.1541-1549, 2013. Available from: <https:// www.researchgate.net/publication/256465190_Effect_of_plant extracted_smoke_and_reversion_of_abscisic_acid_stress_on_ lettuce>. Accessed: Oct. 12, 2020. ISSN: 05563321.

KARAASLAN, M. A. Effect of some essential oils on the growth of Scenedesmus subspicatus. Ege Journal of Fisheries and Aquatic Sciences, [S.L.], v.35, n.2, p.195-198, 15, 2018. Available from: $<$ http://dx.doi.org/10.12714/egejfas.2018.35.2.13>. Accessed: Oct. 12, 2020. doi: 10.12714/egejfas.2018.35.2.13.

KARABÜYÜK, F.; AYSAN, Y. Antibacterial effects of some plant extracts against tomato bacterial speck disease caused by Pseudomonas syringae pv. tomato. Journal of Tekirdag Agricultural Faculty, 2019. Available from: <https://doi. org/10.33462/jotaf.529499>. Accessed: Oct. 12, 2020. doi: 10.33462 jotaf.529499.

KARABUYUK, F.; AYSAN, Y. Aqueous plant extracts as seed treatments on tomato bacterial speck disease. Acta Horticulturae, [S.L.], n. 1207, p. 193-196, jul. 2018. International Society for Horticultural Science (ISHS). Available from: <http://dx.doi. org/10.17660/actahortic.2018.1207.25>. Accessed: Oct. 12, 2020. doi: 10.17660/actahortic.2018.1207.25.

KHAN, I. A. et al. Effect of different herbicides, plant extracts and mulches on yield and yield components of maize. Planta Daninha, [s.1.], v.38, 2020. Available from: $<$ https://doi.org/10.1590/s010083582020380100028>. Accessed: Oct. 12, 2020. doi: 10.1590/ s0100-83582020380100028.

KOLTZ, E. A. et al. Combining Brassica sachets and extracts with thermotherapy against postharvest green mold of orange. Scientia Horticulturae, [s.1.], v.268, n ${ }^{\circ}$.December 2019, p.109389, 2020. Available from: <https://doi.org/10.1016/j.scienta.2020.109389>. Accessed: Oct. 12, 2020. doi: 10.1016/j.scienta.2020.109389.

KUMAR, A et al. Investigations on variability and ecofriendly management of Alternaria alternata causing tomato blight. Vegetos, 25 (1): 52-58. 2012. Available from: <https:// vegetosindia.org/journal/vegetos-25(1)2012/Investigationson-Variability-and-Eco-friendly-Management-of-Alternariaalternata-Causing-Tomato-Blight.html>. Accessed: Oct. 12, 2020. ISSN: 2229-4473

KUMAR, S, et al. Integrated management of jatropha root rot caused by Rhizoctonia bataticola. Journal of Tropical Forest Science, vol. 23, no.1, 2011, pp.35-41. Available from: <www. jstor.org/stable/23616877>. Accessed: Aug. 10, 2020.

LAKSHMEESHA, T.R. et al. Biofabrication of zinc oxide nanoparticles with Syzygium aromaticum flower buds extract and finding its novel application in controlling the growth and mycotoxins of Fusarium graminearum. Frontiers in Microbiology, 2019. Available from: <https://doi.org/10.3389/ fmicb.2019.01244>. Accessed: Oct. 12, 2020. doi: 10.3389/ fmicb.2019.01244. 
LIMA, C. B et al. Plant extracts and essential oils on the control of Alternaria alternata, Alternaria dauci and on the germination and emergence of carrot seeds (Daucus carota L.). Ciência Rural, [S.L.], v.46, n.5, p.764-770, 2016. Available from: $<$ http://dx.doi. org/10.1590/0103-8478cr20141660>. Accessed: Oct. 12, 2020. doi: $10.1590 / 0103-8478 \mathrm{cr} 20141660$.

MAHAKHAM, W et al. Nanopriming technology for enhancing germination and starch metabolism of aged rice seeds using phytosynthesized silver nanoparticles. Scientific Reports, 2017. Available from: <https://doi.org/10.1038/s41598-017-08669-5>. Accessed: Oct. 12, 2020. doi: 10.1038/s41598-017-08669-5.

MAHMUD, H.; HOSSAIN, I. Comparative efficacy of BAUBiofungicide and synthetic fungicides in management of diseases of rice (Oryza sativa L.) for quality seed production. Brazilian Journal of Botany, 389-397, 2017. Available from: $<$ https://doi. org/10.1007/s40415-017-0361-8>. Accessed: Oct. 12, 2020. doi: $10.1007 / \mathrm{s} 40415-017-0361-8$.

MAMARABADI, M.; TANHAEIAN, A.; RAMEZANY, Y. Antifungal activity of recombinant thanatin in comparison with two plant extracts and a chemical mixture to control fungal plant pathogens. AMB Express, 2018. Available from: <https://doi. org/10.1186/s13568-018-0710-4>. Accessed: Oct. 12, 2020. doi: $10.1186 / \mathrm{s} 13568-018-0710-4$

MANDIRIZA，G.; KRITZINGER，Q; AVELING，T.A. The evaluation of plant extracts, biocontrol agents and hot water as seed treatments to control black rot of rape in South Africa. Crop Protection, [S.L.], v.114, p.129-136, 2018. Available from: $<$ http://dx.doi.org/10.1016/j.cropro.2018.08.025>. Accessed: Oct. 12, 2020. doi: 10.1016/j.cropro.2018.08.025.

MANGWENDE, E. Control of Alternaria leaf spot of coenter in Organic Agriculture. European Journal of Plant Pathology, [s.1.], v.154, n.3, p.575-584, 2019. ISSN: 0929-1873. Available from: <https://doi.org/10.1007/s10658-019-01682-6>. Accessed: Oct. 12, 2020. doi: 10.1007/s10658-019-01682-6.

MASANGWA, J. I. G.; KRITZINGER, Q.; AVELING, T. A $\mathrm{S}$. Germination and seedling emergence responses of common bean and cowpea to plant extract seed treatments. The Journal of Agricultural Science, [S.L.], v.155, n.1, p.18-31, 2016 Available from: $<$ http://dx.doi.org/10.1017/s0021859616000113>. Accessed: Oct. 12, 2020. doi: 10.1017/s0021859616000113.

MASANGWA, J.; AVELING, T.; KRITZINGER, Q. Screening of plant extracts for antifungal activities against Colletotrichum species of common bean (Phaseolus vulgaris L.) and cowpea (Vigna unguiculata (L.) Walp). The Journal of Agricultural Science, 2013. Available from: <https://doi.org/10.1017/ S0021859612000524>. Accessed: Oct. 12, 2020. doi: 10.1017/ S0021859612000524.

MASHELA, P.; POFU, K.; NZANZA, B. Suitability of Brassica oleracea leaves in managing Meloidogyne incógnita through the ground leaching technology system under microplot conditions. Acta Agriculturae Scandinavica, Section B - Soil \& Plant Science, [S.L.], v.63, n.1, p.19-24, 2013. Available from: <http:// dx.doi.org/10.1080/09064710.2012.711351>. Accessed: Oct. 12 2020. doi: $10.1080 / 09064710.2012 .711351$

MAXIMIANO, C. V et al. Physiological and sanitary quality of maize seeds preconditioned in ozonated water. Revista Brasileira de Engenharia Agrícola e Ambiental, [s.1.], v.22, n.5, p.360-
365, 2018. Available from: <http://dx.doi.org/10.1590/18071929/agriambi.v22n5p360-365>. Accessed: Oct. 12, 2020. doi: 10.1590/1807-1929/agriambi.v22n5p360-365

MEENA, R. P. et al. Efficacy of fungicides and plant extracts against Alternaria alternata causing leaf blight of chandrasur (Lepidium sativum). Indian Journal of Agricultural Sciences, [s.1.], v.90, n.2, p.337-340, 2020. Available from: <https://www. researchgate.net/publication/339677934_Efficacy_of_fungicides and_plant_extracts_against_Alternaria_alternata_causing_leaf blight of chandrasur Lepidium sativum $>$. Accessed: Oct. 12, 2020. ISSN: 00195022 .

MEFTAH, H; BOUGHDAD, A; BOUCHELTA, A. Biocide effect of crude aqueous extracts of Capsicum frutescens, Melia azedarach and Peganum harmala on in-orchard Euphyllura olivina Costa (Homoptera, Psyllidae). Cahiers Agricultures, [S.L.], v.20, n.6, p.463-467, 2011. Available from: <http://dx.doi. org/10.1684/agr.2011.0531>. Accessed: Oct. 12, 2020. doi: 10.1684/agr.2011.0531.

MENDOZA, F. C.; CELIS, F., A.; PACHÓN, S. M. Herbicide effects of piper extracts on a seed bank in fusagasuga (Colombia). Acta Horticulturae, [S.L.], n.1030, p.77-82, 2014. Available from: $<$ http://dx.doi.org/10.17660/actahortic.2014.1030.9>. Accessed: Oct. 12, 2020. doi: 10.17660/actahortic.2014.1030.9.

MENGULLUOGLU, M.; SOYLU, S. Antibacterial activities of essential oils extracted from medicinal plants against seed-borne bacterial disease agent. Acidovorax avenae subsp citrulli. Research on Crops, 2012. Available from: <https:/www.researchgate.net/ publication/287723650_Antibacterial_activities_of_essential oils extracted from medicinal plants against seedborne bacterial_disease_agent_Acidovorax_avenae_subsp_citrulli> Accessed: Oct. 12, 2020.

MOLA, I. Di et al. Effect of vegetal- And seaweed extractbased biostimulants on agronomical and leaf quality traits of plastic tunnel-grown baby lettuce under four regimes of nitrogen fertilization. Agronomy, [s.1.], v.9, n.10, 2019. Available from: $<$ https://doi.org/10.3390/agronomy9100571>. Accessed: Oct. 12, 2020. doi: 10.3390/agronomy9100571.

MONTEIRO, T. S. A et al. Redução de inóculo de Aphelenchoides besseyi em sementes de Brachiaria brizantha tratadas com óleos essenciais. Ciência Rural, [S.L.], v.44, n.7, p.1149-1154, 2014. Available from: <http://dx.doi.org/10.1590/0103-8478cr20120383>. Accessed: Oct. 12, 2020. doi: 10.1590/0103-8478cr20120383.

MÜLLER, M. A. et al. In vitro toxicity and control of Meloidogyne incognita in soybean by rosemary extract. Semina: Ciências Agrárias, [s.1.], v.37, no.1, p.103-110, 2016. Available from: <http://dx.doi.org/10.5433/1679-0359.2016v37n1p103>. Accessed: Oct. 12, 2020. doi: 10.5433/1679-0359.2016v37n1p103.

MUÑOZ, C et al. Evaluation of biochar-plant extracts complexes on soil nitrogen dynamics. Journal of Biobased Materials and Bioenergy, [s.1.], v.8, no.3, p.377-385, 2014. Available from: $<$ https://doi.org/10.1166/jbmb.2014.1448>. Accessed: Oct. 12, 2020. doi: $10.1166 / \mathrm{jbmb} .2014 .1448$.

MUTHUKUMAR, A et al. Efficacy of plant extracts and biocontrol agents against Pythium aphanidermatum inciting chilli dampingoff. Crop Protection, [S.L.], v.29, n.12, p.1483-1488, 2010. Available from: < http://dx.doi.org/10.1016/j.cropro.2010.08.009>. Accessed: Oct. 12, 2020. doi: 10.1016/j.cropro.2010.08.009. 
NAHAR, M. N.; SHAMSI, S. In vitro screening of fungicides and plant extracts against six pathogenic fungi isolated from cotton (Gossypium arboreum L.) seed. Bangladesh Journal of Botany, 49(2), 197-204. 2020. Available from: <https://doi.org/10.3329/ bjb.v49i2.49292>. Accessed: Oct. 12, 2020. doi: 10.3329/bjb. v49i2.49292.

NARASIMHAMURTHY, K. et al. Elicitation of innate immunity in tomato by salicylic acid and Amomum nilgiricum against Ralstonia solanacearum. Biocatalysis and Agricultural Biotechnology, [s.1.], v.22, no July, p.101414, 2019. Available from: <https://doi. org/10.1016/j.bcab.2019.101414>. Accessed: Oct. 12, 2020. doi: 10.1016/j.bcab.2019.101414.

NCISE, $W$ et al. Effects of light intensities and varying watering intervals on growth, tissue nutrient content and antifungal activity of hydroponic cultivated Tulbaghia violacea $\mathrm{L}$. under greenhouse conditions. Heliyon, [s.1.], v.6, no.5, 2020. Available from: <https:// doi.org/10.1016/j.heliyon.2020.e03906>. Accessed: Oct. 12, 2020. doi: 10.1016/j.heliyon.2020.e03906.

NGUEFACK, $\mathrm{J}$ et al. Effect of plant extracts and an essential oil on the control of brown spot disease, tillering, number of panicles and yield increase in rice. European Journal of Plant Pathology, [S.L.], v.137, n.4, p.871-882, 28, 2013. Available from: <http:// dx.doi.org/10.1007/s10658-013-0298-0>. Accessed: Oct. 12, 2020. doi: 10.1007/s10658-013-0298-0.

NNEDINMA et al. Identification and control of specific aflatoxinproducing fungi in stored maize seeds in awka using Azadirachta indica (neem) and Garcinia kola Seeds. Pakistan Journal of Pharmaceutical Sciences, 2019; 32(4):1679-1686. Available from: $<$ https://www.pjps.pk/?page_id=4907>. Accessed: Oct. 12, 2020. PubMed PMID: 31608890

OJO, D. O. et al. Effects of Cleistopholis patens (Benth) extracts on cowpea seed beetle, Callosobruchus maculatus (Fab.) (Coleoptera: Chrysomelidae) infesting cowpea seeds in storage. International Journal of Tropical Insect Science, [s.1.], 2020. Available from: $<$ https://doi.org/10.1007/s42690-020-00194-9>. Accessed: Oct. 12, 2020. doi: 10.1007/s42690-020-00194-9.

PARIKH, L. et al. Identification and pathogenicity of Fusarium spp. in row crops in Nebraska. Crop Protection, [s.l.], v.108, no September 2017, p.120-127, 2018. Available from: <https://doi. org/10.1016/j.cropro.2018.02.019>. Accessed: Oct. 12, 2020. doi: 10.1016/j.cropro.2018.02.019.

PAVELA, R. et al. Oviposition inhibitory activity of the Mexican sunflower Tithonia diversifolia (Asteraceae) polar extracts agains the two-spotted spider mite Tetranychus urticae (Tetranychidae). Physiological and Molecular Plant Pathology, [s.1.], v.101, p.85-92, 2018. Available from: <https://doi.org/10.1016/j. pmpp.2016.11.002>. Accessed: Oct. 12, 2020. doi: 10.1016/j. pmpp.2016.11.002.

PEREIRA, A. J. et al. Control of Brevicoryne brassicae (Hemiptera: Aphididae) with extracts of Agave americana var. Marginata Trel. in Brassica oleracea crops. Annals of Applied Biology, [s.l.], v.174, no.1, p.14-19, 2018. Available from: <https://doi. org/10.1111/aab.12471>. Accessed: Oct. 12, 2020. doi: 10.1111/ aab.12471.

PEREIRA, R.B et al. Citronella essential oil in the control and activation of coffee plants defense response against rust and brown eye spot. Ciência e Agrotecnologia, 2012. Available from:
$<$ https://doi.org/10.1590/S1413-70542012000400001>. Accessed: Oct. 12, 2020. doi:10.1590/s1413-70542012000400001.

PHAMBALA, $\mathrm{K}$ et al. Bioactivity of common pesticidal plants on fall armyworm larvae (Spodoptera frugiperda). Plants, [S.L.], v.9, n.1, p.112, 2020. Available from: <http://dx.doi.org/10.3390/ plants9010112>. Accessed: Oct. 12, 2020. doi: 10.3390/ plants9010112.

PODEROSO, J. C. M et al. Effects of Plant extracts on developmental stages of the predator Podisus nigrispinus (Hemiptera: Pentatomidae). Florida Entomologist 99(1), 113-116, 2016. Available from: <https://doi.org/10.1653/024.099.0121>. Accessed: Oct. 12, 2020. doi: 10.1653/024.099.0121.

QUATTRUCCI, A et al. Biological control of tomato bacterial speck using Punica granatum fruit peel extract. Crop Protection, [S.L.], v.46, p.18-22, 2013. Available from: <http://dx.doi. org/10.1016/j.cropro.2012.12.008>. Accessed: Oct. 12, 2020. doi: 10.1016/j.cropro.2012.12.008.

RAFI, $\mathrm{H}$ et al. Seed priming with extracts of Acacia nilotica (L.) Willd. Ex delile and Sapindus mukorossi (L.) Plant parts in the control of root rot fungi and growth of plants. Pakistan Journal of Botany, [s.1.], v.47, no.3, p.1129-1135, 2015. Available from: $<$ https://www.pakbs.org/pjbot/PDFs/47(3)/37.pdf>. Accessed: Oct. 12, 2020. ISSN: 0556-3321.

RAMOS, V. M et al. Bioactivity of Asclepias curassavica, Equisetum spp. and Rosmarinus officinalis extracts against leafcutting ants. Sociobiology, 2019. Available from: $<$ https://doi. org/10.13102/sociobiology.v66i4.4271>. Accessed: Oct. 12, 2020. doi: 10.13102/sociobiology.v66i4.4271.

REHMAN, $\mathrm{H}$ et al. Comparative toxic potential of some plant extracts and spinetoram against Tribolium castaneum (Herbst, 1797) (Coleoptera: tenebrionidae). Turkish Journal of Entomology, [S.L.], p.201-210, 25, 2019. Available from: <http:// dx.doi.org/10.16970/entoted.487623>. Accessed: Oct. 12, 2020. doi: 10.16970 /entoted.487623.

ROCHA, C. H. D et al. Psidium cattleyanumessential oil to control plant pathogens in bean seeds. Revista Verde de Agroecologia e Desenvolvimento Sustentável, [s.1.], v.15, no.1, p.14-19, 2020. Available from: <https://doi.org/10.18378/rvads.v15i1.7365>. Accessed: Oct. 12, 2020. doi: 10.18378/rvads.v15i1.7365.

RODRÍGUEZ, D. J et al. In vitro antifungal activity of extracts of Mexican Chihuahuan desert plants against postharvest fruit fungi. Industrial Crops and Products, [S.L.], v.34, n.1, p.960-966, 2011. Available from: <http://dx.doi.org/10.1016/j. indcrop.2011.03.001>. Accessed: Oct. 12, 2020. doi: 10.1016/j. indcrop.2011.03.001.

RUIZ-COUTIÑO, P et al. Organic management of 'Maradol' papaya (Carica papaya L.) crops: effects on the sensorial and physicochemical characteristics of fruits. Agriculture, [S.L.], v.9, n.11, p.234, 2019. Available from: <http://dx.doi.org/10.3390/ agriculture9110234>. Accessed: Oct. 12, 2020. doi: 10.3390/ agriculture9110234.

SAHAYARAJ, $\mathrm{K}$ et al. Compatibility of entomopathogenic fungi with extracts of plants and commercial botanicals. African Journal of Biotechnology, [s.1.], v.10, no.6, p.933-938, 2018. Available from: <https://doi.org/10.5897/AJB10.252>. Accessed: Oct. 12, 2020. doi: 10.5897/AJB10.252. 
SALJOQI, A et al. Behavioral changes of Heterotermes indicola (Isoptera: Rhinotermitidae) against some natural products. Pakistan Journal of Zoology, 2012. 44: 1613-1622. Available from: <https://www.zsp.com.pk/pdf44/1613-1622\%20 $21 \% 20$ PJZ-495-10\%2012-10-12\%20-Revised\%20Final\%20version. pdf $>$. Accessed: Oct. 12, 2020.

SAS-PIOTROWSKA B.; PIOTROWSKI, W. Vitality and healthiness of cereal grains treated with plant decoctions. Rocznik Ochrona Srodowiska, 2011. Available from: <https:// www.researchgate.net/publication/293495982 Vitality and healthiness_of_cereal_grains_treated_with_plant_decoctions $>$. Accessed: Oct. 12, 2020.

SCHÜTTE, G. et al. Herbicide resistance and biodiversity: agronomic and environmental aspects of genetically modified herbicide-resistant plants. Environmental Sciences Europe, [s.1.], v.29, no.1, p.5, 2017. Available from: <https://doi.org/10.1186/ s12302-016-0100-y>. Accessed: Oct. 12, 2020. doi: 10.1186/s12302016-0100-y.

SHAPIRO-ILAN, D. I et al. Control of key pecan insect pests using biorational pesticides. Journal of Economic Entomology, [S.L.], v.106, n.1, p.257-266, 2013. Available from: $<$ http://dx.doi. org/10.1603/ec12302>. Accessed: Oct. 12, 2020. doi: 10.1603/ ec12302.

SHIFA, H.; GOPALAKRISHNAN, C.; VELAZHAHAN, R Management of late leaf spot (Phaeoisariopsis personata) and root rot (Macrophomina phaseolina) diseases of groundnut (Arachis hypogaea L.) with plant growth-promoting rhizobacteria, systemic acquired resistance inducers and plant extracts. Phytoparasitica, [S.L.], v.46, n.1, p.19-30, 2018. Available from: <http://dx.doi org/10.1007/s12600-018-0644-Z>. Accessed: Oct. 12, 2020. doi: $10.1007 / \mathrm{s} 12600-018-0644-\mathrm{z}$

SIDDIQUE, B et al. Behavioral responses of Coccinella septempunctata and Diaeretiella rapae under the influence of semiochemicals and plant extract in four arm olfactometer Pakistan Journal of Zoology, 2019. Available from: <http:// dx.doi.org/10.17582/journal.pjz/2019.51.4.1403.1411> Accessed: Oct. 12, 2020. doi: 10.17582/journal. pjz/2019.51.4.1403.1411.

SILVA, F. H. A et al. Aqueous extracts of plants in Colletotrichum gloeosporioides inhibition in vitro and in postharvest guava. Revista Caatinga. 2014; 27 (1):93-99. Available from: <https:// periodicos.ufersa.edu.br/index.php/caatinga/article/view/2954 pdf_90>. Accessed: Oct. 12, 2020.

SILVA, L. G et al. Biochar amendment increases soil microbial biomass and plant growth and suppresses Fusarium wilt in tomato. Tropical Plant Pathology, [s.1.], v.45, no.1, p.73-83, 2020. Available from: <https://doi.org/10.1007/s40858-02000332-1>. Accessed: Oct. 12, 2020. doi: 10.1007/s40858-020$00332-1$

SILVA, L. G.; ANDRADE, C. A.; BETTIOL, W. Biochar amendment increases soil microbial biomass and plant growth and suppresses Fusarium wilt in tomato. Tropical Plant Pathology, [S.L.], v.45, n.1, p.73-83, 2020. Available form: <http://dx.doi. org/10.1007/s40858-020-00332-1>. Accessed: Oct. 12, 2020. doi: $10.1007 / \mathrm{s} 40858-020-00332-1$.

SILVEIRA, H. R. O et al. Alelopatia e homeopatia no manejo da tiririca (Cyperus rotundus). Planta Daninha, [S.L.], v.28, n.3, p.499-506, 2010. Available from: <://dx.doi.org/10.1590/s0100$83582010000300006>$. Accessed: Oct. 12, 2020. doi: 10.1590 / s0100-83582010000300006.

SINGH， R. B.; SINGH, H. K.; PARMAR, A. Integrated management of Alternaria Blight in linseed. Proceedings of the National Academy of Sciences, India Section B-Biological Sciences, [S.L.], v.83, n.3, p.465-469, 5. 2013. Available from: $<$ http://dx.doi.org/10.1007/s40011-012-0152-8>. Accessed: Oct. 12, 2020. doi: 10.1007/s40011-012-0152-8.

SINGH, R. B et al. Integrated management of Alternaria Blight in linseed. Proceedings of the National Academy of Sciences India Section B-Biological Sciences. 83, 465-469. 2013. Available from: <https://doi.org/10.1007/s40011-012-0152-8>. Accessed: Oct. 12, 2020. doi: 10.1007/s40011-012-0152-8.

SINGH, S. et al. Evaluation of components of IPM for basmati rice against rice root-knot nematode, Meloidogyne graminicola. Indian Journal of Agricultural Sciences, [s.1.], 2019. Available from: $<$ https://www.cabdirect.org/cabdirect/abstract/20203531107>. Accessed: Oct. 12, 2020. ISSN: 00195022.

SOARES, M. A. et al. Botanical insecticide and natural enemies: a potential combination for pest management against Tuta absoluta. Journal of Pest Science, [s.1.], v.92, no.4, p.1445, 2019. Available from: <https://doi.org/10.1007/s10340-019-01102-y>. Accessed: Oct. 12, 2020. doi: 10.1007/s10340-019-01102-y.

SZPARAGA, A.; KOCIRA, S. Generalized logistic functions in modelling emergence of Brassica napus L. PLOS ONE, 2018. Available from: <https://doi.org/10.1371/journal.pone.0201980>. Accessed: Oct. 12, 2020. doi: 10.1371/journal.pone.0201980.

TANVEER, $\mathrm{H}$ et al. Assessment of wheat foliar mycofloraand its management strategies in district bhimber, azad kashmir, Pakistan. Applied Ecology and Environmental Research, 2016. Available from: <http://dx.doi.org/10.15666/aeer/1405_049065>. Accessed: Oct. 12, 2020. doi: 10.15666/aeer/1405 049065 .

TAYEL, A et al. Control of citrus molds using bioactive coatings incorporated with fungal chitosan/plant extracts composite. Journal of the Science of Food and Agriculture, 2015. Available from: <http://dx.doi.org/10.1002/jsfa.7223>. Accessed: Oct. 12, 2020. doi: $10.1002 /$ jsfa. 7223 .

TEMBO, $\mathrm{Y}$ et al. Pesticidal plant extracts improve yield and reduce insect pests on legume crops without harming beneficial arthropods. Frontiers in Plant Science, 2018. Available from: <https://doi.org/10.3389/fpls.2018.01425>. Accessed: Oct. 12, 2020. doi: $10.3389 /$ fpls.2018.01425.

UMARUSMAN, M. A.; AYSAN, Y; ÖZGÜVEN, M. Investigation of the antibacterial effects of different plant extracts against pea bacterial leaf blight disease caused by Pseudomonas syringae pv. pisi. Tekirdağ Ziraat Fakültesi Dergisi, [S.L.], p.297-314, 18, 2019. Available from: <http:// dx.doi.org/10.33462/jotaf.527213>. Accessed: Oct. 12, 2020. doi: 10.33462/jotaf.527213.

VICENTINI, V. B et al. Ethanol extract of Cymbopogon winterianus on mortality and number of eggs of Tetranychus urticae. Ciência Rural, [S.L.], v.45, n.7, p.1154-1159, 2015. Available from: <http://dx.doi.org/10.1590/0103$8478 \mathrm{cr} 20140175>$. Accessed: Oct. 12, 2020. doi: 10.1590/0103$8478 \mathrm{cr} 20140175$ 
VIOLETH, J. L. B.; HERRERA, C. F.; GARCÍA, K. D. P. Plant extracts: alternative control Colaspis sp. (Coleoptera: Chrysomelidae) in banana cv. Harton. Temas Agrarios, [S.L.], v.23, n.1, p.9-17, 19, 2018. Available from: <http://dx.doi.org/10.21897/rta.v23i1.1142>. Accessed: Oct. 12, 2020. doi: 10.21897/rta.v23i1.1142.

WORDELL FILHO, J. A. et al. Pragas e doenças do milho: Diagnose, danos e estratégias de manejo. Empresa de Pesquisa Agropecuária e Extensão Rural de Santa Catarina, [s.1.], p.82,
2016. Available from: <https://publicacoes.epagri.sc.gov.br/BT/ article/view/430/325>. Accessed: Oct. 12, 2020.

ZAKA, S. M. et al. Toxic effects of some insecticides, herbicides, and plant essential oils against Tribolium confusum Jacquelin du val (Insecta: Coleoptera: Tenebrionidae). Saudi Journal of Biological Sciences, [s.1.], v.26, no.7, p.1767-1771, 2019. Available from: <https://doi.org/10.1016/j.sjbs.2018.05.012>. Accessed: Oct. 12, 2020. doi: 10.1016/j.sjbs.2018.05.012. 